\title{
Implementasi Sendai Framework Terhadap Respons Bencana Alam Di Filipina Tahun 2016-2020
}

\author{
Safira Tasya Asadel ${ }^{1}$, Andi Kurniawan ${ }^{1}$, M. Chairil Akbar Setiawan ${ }^{\text {** }}$ \\ ${ }^{1}$ Jurusan Hubungan Internasional, Universitas Pembangunan Nasional Veteran Jakarta, 12540, Jakarta-Indonesia
}

Info Artikel

Dikirim: 03 Nov, 2021

Diterima: 25 Jan, 2022

Dipublikasi: 31 Jan, 2022

Kata Kunci:

Filipina; Keamanan

Manusia; Respon Bencana;

Sendai Framework;

Koresponden:

M. Chairil Akbar Setiawan

Jurusan Hubungan

Internasional, Universitas

Pembangunan Nasional Veteran

Jakarta, 12540, Jakarta-

Indonesia

Email:

mchairilakbars@upnvj.ac.id

\section{Sitasi Cantuman:}

Asadel, S. T., Kurniawan, A. \& Setiawan, M. C. A. (2022). Implementasi Sendai

Framework Terhadap Respons Bencana Alam Di Filipina Tahun 2016-2020. Journal of Political Issues. 3(2); 86-97. https://doi.org/10.33019/jpi.v3i 2.70

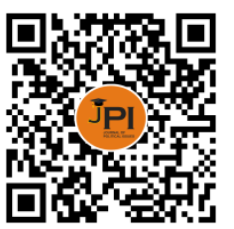

DOI:

https://doi.org/10.33019/jpi.v3i 2.70

Lisensi:

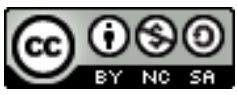

Attribution-NonCommercialShareAlike 4.0 International (CC- BY-NC-SA 4.0)

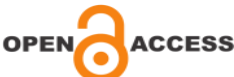

\begin{abstract}
ABSTRAK
Abstract The Provincial Government of DKI Jakarta provides the application of the Electronic Information-Based It is undeniable, disasters can be a big threat in the field of economic, social, political, and others for the affected areas. Started from the various major disasters that occurred one of them was the Tsunami in Aceh in 2004, a framework for cooperation between countries was born that contained a strategy and a systematic approach to reducing vulnerability and risk of hazards called the Hyogo Framework of Action (HFA) which was adopted in 2005-2015. Due to its success in several respects, various countries agreed to continue this collaboration called the Sendai Framework for Disaster Risk Reduction (SFDRR) which was adopted in 2015-2030. The Philippines as a country that is prone to disasters such as typhoons because it is located in The Pacific Ring of Fire participated in ratifying the cooperation voluntarily. One form of commitment from the Philippines is to implement the Build Back Better program and carry out good collaboration with national and international actors. Through this research, researchers want to see how SFDRR can help The Philippines as a disasterprone country develops its disaster management, especially in emergency response.
\end{abstract}

Abstrak Tidak dapat dipungkiri, bencana dapat menjadi ancaman besar baik di bidang ekonomi, sosial, politik, dan lain-lain bagi wilayah terdampak. Berawal dari berbagai bencana besar yang terjadi salah satunya Tsunami di Aceh tahun 2004, lahirlah sebuah kerangka kerjasama antar negara yang berisi strategi dan pendekatan sistematis untuk mengurangi kerentanan dan risiko bahaya yang bernama Hyogo Framework of Action (HFA) yang diadopsi di tahun 2005-2015. Karena keberhasilannya di beberapa hal, berbagai negara sepakat untuk melanjutkan kerjasama ini yang bernama Sendai Framework for Disaster Risk Reduction (SFDRR) yang diadopsi di tahun 2015-2030. Filipina sebagai negara yang rentan akan bencana seperti angin topan karena berlokasi di Cincin Api Pasifik turut serta dalam meratifikasi kerjasama tersebut secara sukarela. Salah satu bentuk komitmen dari Filipina adalah melaksanakan program Build Back Better dan melaksanakan kolaborasi baik dengan aktor nasional maupun internasional. Melalui penelitian ini peneliti ingin melihat bagaimana SFDRR dapat membantu Filipina sebagai negara rentan bencana mengembangkan manajemen bencananya khususnya di dalam tanggap darurat bencana.

Tentang:

Safira Tasya Asadel, adalah mahasiswa di Jurusan Hubungan Internasional Universitas Pembangunan Nasional Veteran Jakarta

Andi Kurniawan, menyelesaikan studi S2 di Universitas Indonesia pada tahun 2013. Saat ini penulis merupakan dosen tetap di Jurusan Hubungan Internasional Universitas Pembangunan Nasional Veteran Jakarta

M. Chairil Akbar Setiawan, menyelesaikan studi S2 di Universitas Gadjah Mada pada tahun 2015. Saat ini penulis merupakan dosen tetap di Jurusan Hubungan Internasional di Universitas Pembangunan Nasional Veteran Jakarta. 


\section{PENDAHULUAN}

Dengan lahirnya ilmu hubungan internasional pada masa-masa awal Perang Dunia II, bencana menjadi isu utama. Krisis Rudal Kuba pada tahun 1962 menandai dimulainya manajemen darurat dan pengembangan pertahanan sipil yang bertujuan melindungi pemerintah dan masyarakat dari dampak perang nuklir. Ketika Uni Soviet menembakkan rudal, pembuat kebijakan pertahanan melakukan pekerjaan identifikasi untuk mengevakuasi pejabat publik dan warga AS. Selain proses pelembagaan penanggulangan bencana, Amerika Serikat juga mendanai penelitian bencana untuk mengetahui perilaku manusia dalam merespon bencana (Sinulingga, 2016).

Sendai Framework for Disaster Risk Reduction (SFDRR) periode 2015-2030 merupakan sebuah bentuk perjanjian antar negara yang menandatangani perjanjian tersebut untuk melakukan manajemen bencana di negaranya masing-masing. Kerangka ini sendiri diadopsi dari Third United Nations World Conference on Disaster Risk Reduction yang diselenggarakan pada tanggal 14 sampai 18 Maret 2015 bertempat di Sendai, Miyagi, Jepang. Ada beberapa indikator prioritas suatu negara untuk memenuhi komitmennya di bawah SFDRR, yaitu:

1. Prioritas 1: Memahami risiko bencana

2. Prioritas 2 : Memperkuat manajemen risiko bencana

3. Prioritas 3: Berinvestasi dalam pengurangan risiko bencana untuk meningkatkan ketahanan

4. Prioritas 4: Meningkatkan kesiapsiagaan bencana untuk respons yang efektif dan "Build Back Better"

Dari beberapa negara di Asia Tenggara, Filipina merupakan negara yang menarik untuk dibahas karena Filipina rentan terhadap bencana alam. Filipina adalah negara kepulauan, yang secara resmi dikenal sebagai Republik Filipina, dengan 7.107 pulau. Karena negara yang terletak di Cincin Api Pasifik, Filipina rentan terhadap bencana seperti angin topan, letusan gunung berapi, gempa bumi, banjir, tsunami, tanah longsor, dan kekeringan. Penyebab terjadinya bencana alam ini adalah faktor iklim dan lingkungan yang tidak stabil. Selain terletak di Cincin Api Pasifik, Filipina juga sangat aktif dalam aktivitas seismik. Selain di wilayah Palawan, juga terdapat risiko tinggi terkait kenaikan muka air laut di sepanjang pantai Filipina, yang meningkatkan risiko tersebut. Filipina rentan terhadap bencana alam, bencana biasanya menyebabkan bencana lain, sehingga bencana ini saling terkait. Selain menimbulkan kerawanan masyarakat dan dampak ekonomi, bencana yang saling terkait inilah yang menyebabkan kerusakan parah pada infrastruktur dan perumahan. Beberapa bencana di Filipina antara lain letusan gunung Mayon pada Januari 2018, Badai Tropis Tembin pada Desember 2017, dan gempa Juli 2017 (CEDM-HA, 2018).

Penanggulangan bencana di Filipina sendiri berawal dari Perang Dunia II dan lebih fokus pada persiapan perang. Presiden Manuel Quezon mengeluarkan Executive Order EO335 pada tahun 1941 untuk mempersiapkan penduduk jika terjadi perang yang meluas ke kawasan Pasifik dan mengambil langkah-langkah untuk mengelola dan mengoordinasikan keterlibatan sipil dalam keadaan darurat dengan membuat manajemen darurat sipil. Di bawah EO335, National Emergency Commission dibentuk bekerja sama dengan Provincial Emergency Committee yang didirikan di setiap negara bagian dan diawasi oleh Municipal Emergency Committees dan City Emergency Committees. Kemudian pada bulan November 1968 dibuat Executive Order EO159 yang menetapkan organisasi penanggulangan bencana di instansi pemerintah, antara lain instansi pemerintah, instansi pemerintah, instansi pemerintah, instansi pemerintah, instansi dan bidang politik, serta badan usaha milik negara. EO159 dibuat sebagai tindakan pencegahan jika terjadi bencana, tetapi misi ini terhambat oleh biaya (World Bank, 2005). 
Pada tahun 2010, Parlemen memberlakukan Republic Act 10121 (RA 10121) terkait dengan undang-undang manajemen dan mitigasi risiko bencana di Filipina. Peraturan ini bertujuan untuk meningkatkan ketahanan masyarakat dan negara yang rentan terhadap bencana alam serta mengurangi kerusakan dan kerugian jiwa serta harta benda yang diakibatkan oleh bencana. RA10121 mengembangkan kebijakan dan rencana untuk semua aspek penanggulangan bencana, termasuk tata kelola yang baik, penilaian risiko dan sistem peringatan dini, kesadaran dan pemahaman, pengurangan faktor risiko, respons yang efektif dan kesiapan pemulihan dini, serta kebijakan dan tindakan. Peraturan ini merupakan inisiatif yang komprehensif, komprehensif dan terintegrasi untuk memitigasi dampak sosial ekonomi dan lingkungan dari bencana seperti perubahan iklim, terutama keterlibatan dan partisipasi pemangku kepentingan di semua sektor dan tingkatan (Commision on Audit).

Dalam penelitian ini, penulis meninjau beberapa literatur seperti "Philippines: Disaster Risk Profile and Disaster Risk Reduction (DRR) Framework: Natural Calamities" yang ditulis oleh Harold James E. Doroteo. Di dalam literatur ini menjelaskan bahwa Filipina pada dasarnya terkena gempa bumi, letusan gunung berapi, tanah longsor, banjir dan angin topan dan bencana alam lainnya. Rata-rata, 20 gempa bumi diamati setiap hari (kebanyakan terlalu lemah untuk dirasakan). Lokasinya yang berada di Pacific Hurricane Belt/Highway juga membuatnya rentan terhadap kejadian cuaca ekstrim. Garis pantai yang luas juga rentan terhadap tsunami, membuat negara ini rentan terhadap naiknya permukaan laut dan gelombang badai. Hal ini pada gilirannya menyebabkan fenomena sekunder, banjir, tanah longsor, angin muson (sangat kuat), dan kekeringan. Karena terletak di Cincin Api Pasifik, negara ini sering mengalami gempa bumi dan aktivitas vulkanik. Sejak lempeng tektonik besar telah terjadi di daerah ini, data statistik tentang gempa bumi besar berkekuatan lebih kecil sangat teratur. Telah terjadi 5 gempa bumi dahsyat dan korban jiwa dalam dua dekade terakhir (1990-2010), 15 di antaranya tewas dan 119 luka-luka. Kerugian ekonomi diperkirakan mencapai 207 juta peso Filipina. Gempa bumi Luzon 1990, tsunami Teluk Morro dan runtuhnya Menara Ruby adalah yang terburuk (Doroteo, 2015) .

Literatur yang juga digunakan penulis berjudul "Five Years Beyond Sendai - Can

We Get Beyond Frameworks?" oleh Ben Wisner. Artikel ini mengajukan berbagai pertanyaan yang muncul selama 5 tahun adopsi Sendai Framework dilakukan oleh beberapa negara. Beberapa pertanyaan yang diajukan adalah terkait pemahaman tentang bencana, dan tindakan pemerintah dan pengakuan Hak Asasi Manusia (HAM) di dalam HFA dan SFDRR. Terkait pemahaman tentang bencana, peneliti menjelaskan bahwa bencana tidaklah "alami" dan menyimpulkan bencana alam adalah konsep yang salah dan menyesatkan. Proses fisik yang membahayakan atau kegiatan alam menjadikan manusia rentan dan terekspos oleh bencana. Kerentanan disebut sebagai sesuatu yang situasional dan bukanlah karakteristik yang permanen. Sekelompok orang yang rentan dibuat rentan karena proses sosial dan banyak kemungkinan sekelompok orang tersebut menjadi semakin rentan atau semakin tangguh dengan keputusan kebijakan. Pasca 2015, terdapat tujuh inisatif yang terjadi akibat dinamika dari geopolitik dan politik intra dan antar lembaga dengan janji bahwa akan adanya perdamaian yang tercipta pasca 2030. Tujuh inisiatif tersebut meliputi (i) Sustainable Development Goals, (ii) Paris Agreement (meliputi UN Framework Convention on Climate Change), (iii) Addis Ababa Action Agenda (Financing for Development), (iv) World Humanitarian Summit, (v) New Urban Agenda, (vi) berbagai inisiatif perdamaian dan keamanan regional, serta (vii) Sendai Framework (Wisner, 2020) .

Berkaitan dengan hal tersebut, penulis tertarik untuk mengangkat tema manajemen bencana dalam fase respon bencana karena Filipina adalah salah satu negara yang rentan bencana dan telah menyambut baik diadopsinya SFDRR dengan ikut meratifikasi SFDRR pada tanggal 19 Maret 2015 yang diharapkan dapat menjadi acuan bagi pemerintah Filipina atau instansi terkait untuk fokus pada penanggulangan bencana di Filipina. 


\section{METODE PENELITIAN}

Dalam penelitian ini, peneliti memutuskan untuk memakai metode penelitian kualitatif. Penelitian kualitatif memiliki deskripsi yang berbeda-beda seperti menurut John W. Cresswell, penelitian kualitatif adalah cara untuk menggali dan memahami pentingnya banyak individu atau kelompok orang untuk masalah sosial dan kemanusiaan. Sementara, menurut Norman K. Denzin dan Yvonna S. Lincoln, penelitian kualitatif mencakup interpretasi dunia dan metode naturalistik. Artinya peneliti kualitatif yang mempelajari halhal di lingkungan alam berusaha memahami atau menjelaskan fenomena berdasarkan makna yang diberikan oleh manusia. (Bakry, 2016) Untuk data yang digunakan, penulis akan menggunakan data primer yang didapatkan dari hasil wawancara dan data sekunder yang didapatkan dari buku, artikel jurnal, maupun situs berita atau situs pemerintah.

\section{LANDASAN TEORITIK}

\section{Human Security}

Keselamatan manusia itu sendiri memiliki dua arti: pertama, perlindungan terhadap ancaman kronis seperti kelaparan, penyakit dan penindasan. Kedua, perlindungan terhadap gangguan yang tiba-tiba dan berbahaya terhadap gaya hidup masyarakat, baik di rumah, di tempat kerja maupun di masyarakat (Azis, 2004) Dalam hal ini, United Nations Development Programme (UNDP) memiliki indikator keselamatan sendiri untuk memastikan bahwa keselamatan manusia tidak tergantikan, dengan indikator seperti keamanan ekonomi, nutrisi, kesehatan, lingkungan dan keamanan pribadi, publik dan politik.

Terdapat dua pernyataan terkait kerjasama yang pertama, menyelesaikan masalah tertentu, hal ini bisa terjadi antar negara yang bahkan saling bermusuhan seperti Amerika Serikat dan Uni Soviet selama Perang Dingin atau Israel dan Hizbullah dalam pertukaran tahanan mereka, antagonis, bahkan musuh, bekerja sama pada kesempatan untuk menyelesaikan masalah tertentu, tanpa menangani konflik yang lebih luas - dengan kata lain, untuk mengelola tetapi tidak menyelesaikan masalah mereka. konflik. Arti kedua dari istilah tersebut, menggambarkan suatu hubungan, mengacu tidak hanya pada interaksi tertentu tetapi juga menyiratkan keinginan dari pihak aktor untuk memelihara dan mendorong interaksi tersebut melalui pemecahan masalah bersama. Multilateral juga memiliki dua bentuk, dalam arti strategi diplomatik yang digunakan oleh negara-negara untuk mengkoordinasikan kebijakan di antara tiga atau lebih aktor atau kerjasama dalam arti kedua. Multilateral lainnya sebagai kata sifat tanpa isme sering digunakan untuk merujuk pada taktik ad hoc yang diadopsi oleh negara atau kelompok negara dalam mengejar tujuan yang ditentukan, dalam definisi pertama kerjasama (Zartman \& Touval, 2010). Selain pendekatan kolaboratif, pendekatan transdisipliner juga penting untuk dilakukan dalam menjamin keamanan insani dengan mengajak seluruh individu untuk melakukan analisis baik di tingkat lokal, nasional, regional, maupun global (Ramadayanti, 2020)

Filipina sebagai negara yang rawan akan bencana perlu untuk melakukan penanggulangan bencana dengan perspektif human security. Hal ini disebabkan karena di konsep tersebut individu menjadi referent yang berarti pengidentifikasian terkait keamanan yang harus diperhatikan diutamakan kepada individu. Filipina telah mengutus dewan yang dapat mengambil alih tanggung jawab National Disaster Risk Management Council (NDRRMC) di tingkat provinsi, kota, maupun pedesaan sehingga dengan konsep ini kita dapat melihat lebih jauh apakah pendekatan yang telah dilakukan telah sesuai dengan prinsip keamanan manusia. Tipe-tipe ancaman yang dihadapi juga diperhatikan di dalam konsep ini. Filipina telah melakukan pemetaan terkait wilayah dengan risiko tinggi terhadap bencana sebagai wujud identifikasi dalam persiapan pra bencana. Pemetaan ini penting untuk 
mengetahui apa yang dapat dilakukan dan dipersiapkan untuk mewujudkan negara yang tangguh akan ancaman bencana yang terus mengintai.

\section{Manajemen Bencana dan International Norms}

Sesuai dengan Undang-Undang No. 24 Tahun 2007, bencana alam adalah peristiwa atau rangkaian peristiwa yang mengancam atau menghancurkan kehidupan dan penghidupan masyarakat baik karena faktor alam maupun tidak alami dan faktor manusia, yang mengakibatkan kerusakan jiwa, kerusakan lingkungan, harta benda dan efek psikologis. Definisi penderitaan juga mencakup tiga aspek utama yakni terjadinya suatu peristiwa atau kegagalan menimbulkan ancaman dan kerusakan, suatu peristiwa atau hambatan yang mengancam kehidupan, keberadaan dan keberfungsian masyarakat, dan ancaman yang menyebabkan hilangnya nyawa dan menghalangi masyarakat untuk mengelola sumber daya (Purnama, 2017)

Selain itu, bencana alam juga dapat dipahami sebagai kerusakan serius yang disebabkan oleh fenomena alam atau aktivitas manusia. Bencana alam dapat menyebabkan hilangnya nyawa, kerusakan harta benda dan kerusakan serius pada lingkungan. Akibatnya, konsekuensi dari bencana alam sangat parah dan tidak berdaya bagi masyarakat yang terkena dampak dan membutuhkan. Ancaman dapat timbul dari kejadian alam yang ekstrim yang dapat menyebabkan kerusakan dan membahayakan nyawa manusia, kerugian harta benda, hilangnya mata pencaharian dan kerusakan lingkungan. Bencana seperti tanah longsor, banjir, gempa bumi, dll bisa disebut ancaman. Sedangkan kerentanan adalah kondisi yang mengurangi kemampuan masyarakat yang terkena dampak untuk bersiap menghadapi bahaya atau ancaman bencana. Risiko itu sendiri merupakan peluang yang muncul dan menimbulkan kerugian akibat ancaman keamanan dan/atau kerentanan. Potensi adalah sumber daya atau kekuatan yang dimiliki masyarakat dan lingkungannya yang memungkinkannya untuk secara cepat mencegah, mempersiapkan diri, merespons, dan pulih dari bencana alam. Jika kita mempertimbangkan penilaian risiko bencana alam, ancaman dan kerentanan masyarakat di daerah yang terkena dampak dapat dikurangi jika mereka memiliki kapasitas yang sesuai (PMI, 2007)

\section{Gambar 1 Siklus Bencana}

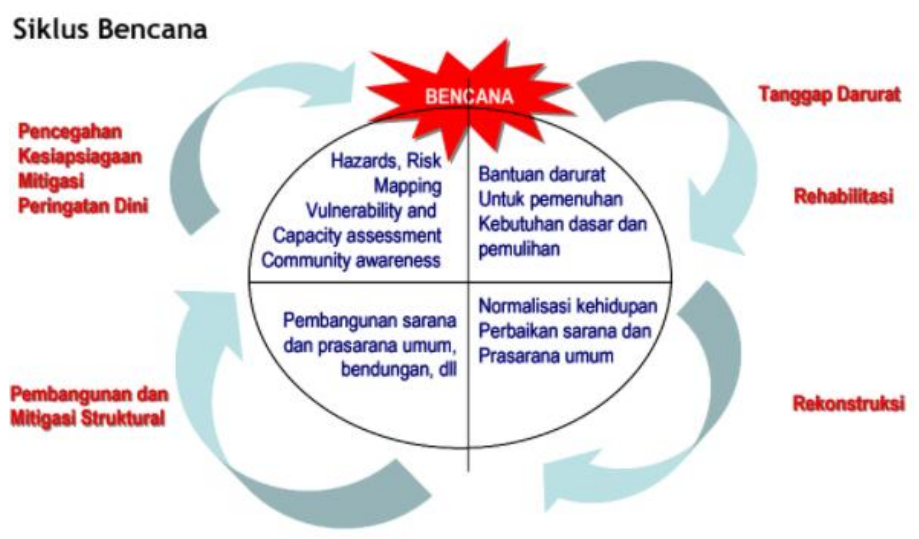

Sumber: Materi - Pengantar Manajemen Bencana Pelatihan KSR Dasar, 2007

Selain itu, SFDRR menjadi sebuah international norms yang disetujui dan ditandatangani oleh beberapa negara sebagai suatu aturan yang mengatur manajemen bencana. International norms telah ada sejak zaman dahulu dibuktikan dengan artifak yang ditemukan oleh para arkeologis di Sungai Nil, yang menjelaskan hubungan diplomatic antara Mesir dan kekuatan besar tetangganya di masa dinasti New Kingdom abad ke-18. Artifak 
yang ditulis dengan Bahasa Akkadian ini menunjukan bahwa negara antar bagian telah mengadopsi sebuah kode perilaku yang memuat hak dan kewajiban berdasarkan peringkat, protokol yang harus diterapkan saat berinteraksi, serta memegang teguh kepercayaan bersama tentang sikap yang tepat. Beberapa dekade terakhir ini peneliti mulai mengapresiasi international norms sehingga mereka mulai menganalisis dampaknya di berbagai arena kebijakan termasuk hak asasi manusia, intervensi kemanusiaan, sanksi, korupsi, monitor pemilihan, persenjataan, imigrasi, dll. Di awal abad ke-20, Presiden United States Barack Obama menyebutkan bahwa seluruh negara harus mematuhi standar yang memerlukan kekuatan sehingga hal tersebut dapat memperkuat mereka yang patuh dan mengisolasi mereka yang melanggar. International norms adalah bagian yang tidak dapat terpisahkan dengan politik dunia dan menjadi bagian dari kebijakan luar negeri. Norma dianggap sebagai sumber informasi bagi para pembuat keputusan bagaimana negara harus bertindak di suatu isu dan apa yang dapat dilakukan di situasi terkini (Raymond, 2021)

Filipina yang telah meratifikasi SFDRR dapat melihatnya sebagai international norms yang menjadi acuan oleh pemerintah untuk mengambil keputusan serta mengatur bagaimana manajemen bencana harus dijalankan di Filipina. Dengan adanya SFDRR, Filipina dapat memperbaiki dan meninjau kembali apakah tindakan yang telah mereka lakukan telah sesuai dan apa yang seharusnya diperbaiki sehingga kapasitas yang dimiliki oleh Filipina dalam melakukan tanggap darurat bencana menjadi lebih baik lagi.

\section{HASIL DAN PEMBAHASAN}

\section{Ancaman Insani di Filipina}

Dalam hal iklim, Filipina adalah salah satu yang paling rentan terhadap dampak buruk. Perubahan iklim yang disebabkan oleh ekosistem yang rapuh (termasuk terumbu karang dan lautan) Fauna), populasi pesisir yang besar, efek cuaca yang sering terjadi Ekstrem di mana kekuatan cenderung meningkat. Dampak perubahan iklim diperhitungkan Ini akan menjadi faktor penting yang menyebabkan topan yang lebih kuat dan naiknya permukaan laut. Meningkatnya gelombang badai di wilayah pesisir. Gelombang badai yang kuat diperkirakan akan berdampak Lebih dari $40 \%$ penduduk pesisir tinggal di permukiman informal, Kemungkinan akan menghadapi efek pertama dari gelombang badai dan banjir (CEDM-HA, 2018)

Menurut laporan World Risk Index 2020, Filipina memiliki angka yang cukup tinggi dari tingkat ancaman terhadap cuaca ekstrim di 2020 dengan skor 42.30. Indikator ini menjelaskan bahwa tingkat ancaman kepada suatu masyarakat dari akibat cuaca ekstrim.

Tabel 1 Skor Negara dengan Cuaca Ekstrim

\begin{tabular}{|l|r|r|}
\hline \multicolumn{1}{|c|}{ Country } & Score & Level \\
\hline Vanuatu & 86.77 & Very high \\
\hline Tonga & 61.21 & Very high \\
\hline Dominica & 62.74 & Very high \\
\hline Antigua and Barbuda & 68.92 & Very high \\
\hline Solomon Islands & 40.04 & Very high \\
\hline Guyana & 44.92 & Very high \\
\hline Brunei Darussalam & 57.61 & Very high \\
\hline Papua New Guinea & 30.79 & Very high \\
\hline Philippines & 42.30 & Very high \\
\hline Guatemala & 36.52 & Very high \\
\hline
\end{tabular}

Sumber: World Risk Index, 2020

\section{Upaya Kolaboratif Antar Sektor}


Respons bencana di Filipina umumnya dilakukan oleh NDRRMC atau organisasi dibawah NDRRMC yang berada di tingkatan area, provinsi, kota/kabupaten, ataupun barangay (perkampungan). Pedoman yang dapat dilakukan dalam melakukan respons bencana sendiri telah dijelaskan di dalam National Disaster Risk Reduction and Management Plan 2020-2030 (NDRRMP). NDRRMP adalah dokumen yang dirumuskan dan dilaksanakan oleh Office of Civil Defense (OCD) yang menetapkan tujuan dan sasaran khusus untuk mengurangi risiko bencana bersama-sama dengan tindakan terkait untuk mencapai tujuan ini sesuai dengan RA 10121. Tujuan dari NDRRMP sendiri adalah untuk memberikan arahan dan panduan strategis kepada pemerintah nasional, pemerintah daerah, organisasi masyarakat, sektor swasta dan mitra di bidang bencana dan ketahanan iklim di Filipina, memperkuat tata kelola bencana dan iklim, serta berkontribusi terhadap norma internasional yang telah disetujui yang salah satunya adalah SFDRR. Untuk memastikan koherensi dan kepatuhan terhadap kerangka waktu pembangunan dan kebijakan global dan nasional agenda, cakupan dokumen ini adalah dari tahun 2020 sampai dengan 2030. Sejalan dengan itu, dokumen tersebut harus diimplementasikan, dipantau, dan dievaluasi berdasarkan kerangka waktu berikut: jangka pendek (2020-2022), jangka menengah (2023-2025), dan jangka panjang (2026-2030) (OCD, 2020)

Untuk menghadapi bencana alam besar dan pemerintah telah menetapkan bahwa negara sedang dalam situasi genting, Filipina mungkin akan mendapatkan permintaan khusus untuk melakukan pendampingan yang memenuhi gap yang dimiliki Filipina dalam kapasitas nasional. Philippine International Humanitarian Assistance Cluster (PIHAC) adalah kerangka institusi dan koordinasi dalam melakukan mobilisasi pendampingan internasional. Terdapat pula Philippines International Humanitarian Assistance Reception Center (PIHARC) yang menjadi one-stop-shop yang memfasilitasi penyaringan, proses ekspedisi dan masuknya tim kemanusiaan internasional, peralatan dan donasi dalam bentuk apapun. Apabila pemerintah meminta atau menyetujui pendampingan internasional, koordinasi akan diinisiasi diantara agensi yang memimpin masing-masing klister. PIHAC dipimpin oleh Department of Foreign Affairs (DFA) bersama dengan Department of Social Welfare and Development (DSWD), Department of Health (DOH), Department of National Defense (DND), Department of Finance (DOF) dan Department of Budget and Management (DBM) untuk mengatur donasi yang datang dari mitra internasional. Sejak Filipina menandatangani HFA di tahun 2005, negara tersebut telah mengembangkan kapasitasnya untuk membangun ketahanan akan bencana bersama dengan ratifikasi. Sebelum adanya SFDRR, Pemerintah Republik Filipina telah menandatangani RA 10121 di tanggal 27 Mei 2010. RA 10121 adalah peraturan mengenai tindakan penguatan sistem penanggulangan dan manajemen bencana Filipina, Penyediaan kerangka pengurangan dan pengelolaan risiko bencana nasional, Pelembagaan rencana penanggulangan dan penanggulangan risiko bencana nasional, Alokasi pendanaan, dan lainnya. RA 10121 juga dikenal sebagai "Philippine Disaster Risk Reduction and Management Act of 2010". Dalam peraturan inilah Filipina mengatur mengenai penguatan kapasitas untuk PRB, kerjasama internasional, promosi rencana PRB, dan lainnya.

Sementara itu, sumber daya manusia juga hadir dari Philippine Red Cross (PRC) dengan sukarelawan yang siap membantu dalam respons bencana. Volunteer Service Office menangani program yang bertujuan untuk mendorong orang khususnya warga Filipina untuk menjadi sukarelawan dengan berbagi sumber daya, waktu, dan upaya meringankan penderitaan manusia. Tetapi, PRC tidak menutup kemungkinan apabila ada sukarelawan dari luar negeri yang ingin bergabung untuk membantu. Kemudian, AHA Centre juga menyediakan sukarelawan di dalam program AHA Centre yang berfokus pada respons bencana yaitu ASEAN-Emergency Response and Assessment Team (ASEAN-ERAT). Anggota dari ASEAN-ERAT sendiri beragam, dimulai dari NDMOs dan otoritas pemerintah terkait, kemudian masyakat sipil, Perhimpunan Palang Merah dan Bulan Sabit Merah, sektor 
swasta, dan akademisi. Hingga di tahun 2020, ASEAN-ERAT telah mencapai lebih dari 300 anggota yang datang dari 10 negara anggota ASEAN dan 32 pelatih yang siap memberikan pelatihan kepada calon anggota ASEAN-ERAT dan memberikan pelatihan lanjutan terhadap anggota lainnya (AHA Centre, 2020)

\section{Hambatan dalam Implementasi Sendai Framework}

Setelah Filipina menandatangani SFDRR, Filipina telah menjadikan SFDRR sebagai salah satu norma internasional yang menjadi panduan dalam mengambil keputusan maupun mengimplementasikan manajemen bencana yang tepat. Tetapi dalam proses manajemen bencana khususnya respons bencana di lapangan, ditemukan beberapa hambatan yang terjadi selama proses respons bencana.

Prioritas pertama dari SFDRR menyebutkan perlunya pemahaman resiko bencana. Menurut penelitian yang dilakukan oleh Senate Economic Planning Office di Filipina walaupun pemerintah Filipina telah menetapkan Kerangka Pendidikan untuk Bencana masih banyak ditemukan masyarakat yang kurang paham akan resiko bencana khususnya yang terjadi di wilayahnya. Selain itu, bencana juga seringkali menjadi isu sampingan sehingga perhatian akan bencana dalam bentuk sumber daya maupun penelitian masih kurang dilaksanakan.

Kemudian, di dalam prioritas kedua disebutkan bahwa perlunya memperkuat tata kelola bencana untuk mengurangi resiko bencana. Sebenarnya, pemerintah Filipina telah mengeluarkan berbagai kebijakan akan bencana khususnya kebijakan dengan SFDRR sebagai latar belakangnya. Hal ini ditunjukkan dengan adanya National Defense Strategy 2018-2022, NDRRMP, NDRP, PDP 2017-2022, dan berbagai kebijakan lainnya. Sebelum penandatangan SFDRR, pemerintah Filipina juga telah mengeluarkan RA 10121 yang menjadi bukti nyata keseriusan pemerintah Filipina dalam mengatur pengurangan resiko bencana dan manajemen bencana khususnya setelah terjadi angin topan Haiyan di tahun 2013 yang menjadi salah satu kasus bencana angin topan di Filipina yang menyebabkan jumlah korban jiwa dan kerugian terbesar. Tetapi dengan berbagai kebijakan tersebut pemerintah masih kurang mengimplementasikan kebijakan manajemen bencana.

Prioritas ketiga di SFDRR menyebutkan bahwa perlunya melakukan investasi pengurangan resiko bencana untuk menciptakan ketahanan. Setiap tahunnya terjadi kenaikan anggaran untuk pengurangan resiko bencana dan manajemen. SFDRR selalu menekankan akan pentingnya untuk mengatasi resiko bencana terlebih dahulu. Sayangnya, pemerintah Filipina masih belum melaksanakan hal ini dengan baik. Hal ini dibuktikan dengan Commision on Audit (COA) melaporkan bahwa alokasi pendanaan bencana menunjukan besarnya pengeluaran yang dikeluarkan saat respons bencana. Ini menunjukkan bahwa pemerintah Filipina lebih mengalokasikan anggarannya saat respons bencana daripada untuk persiapan. Kemudian, Philippine Development Plan (PDP) 2011-2016 pun melaporkan bahwa pencairan dana bencana kepada korban memakan waktu 9-12 bulan. Keterlambatan ini biasanya disebabkan kegagalan pemerintah daerah untuk memenuhi kriteria dan ketentuan yang dibuat oleh institusi pendanaan. Akibatnya, proses respons bencana hingga pemulihan menjadi lebih lambat daripada seharusnya.

Prioritas keempat atau yang terakhir adalah menambah persiapan bencana untuk respons efektif dan "Build Back Better" dalam pemulihan, rehabilitasi, dan rekonstruksi. Untuk melakukan respons efektif, tentunya wilayah tersebut memerlukan kapasitas yang memadai. Kurangnya kapasitas yang dimiliki oleh pemerintah daerah menyebabkan fungsi pengurangan resiko bencana dan manajemen terhambat. Penilaian nasional yang dibuat oleh Biro Pemantauan Pemerintah Daerah di 2013 menunjukan bahwa hanya 23\% pemerintah daerah yang berlokasi di wilayah rentan bencana yang telah siap untuk bencana dalam bentuk pencegahan, kapasitas lembaga, dan koordinasi. Aktivitas pengurangan resiko bencana juga tidak menjadi prioritas utama di beberapa pemerintah daerah dengan beberapa kabupaten 
yang jarang terjadi bencana merasa tiada kepentingan untuk mengimplementasikan program manajemen bencana.

\section{Upaya Pemerintah Filipina}

Di dalam prioritas pertama SFDRR terkait pemahaman resiko bencana, Filipina telah membuat proses signifikan dengan mengumpulkan informasi yang komprehensif dan terkini menggunakan berbagai teknologi seperti GIS, Light Detection and Ranging (LiDAR), Interferometric Synthetic Aperture Radar (IfSAR), simulasi computer, dan pemetaan. Kumpulan informasi inilah yang dapat memberikan pemahaman dalam menentukan resiko bencana dan kerentanan komunitas. Di tingkat nasional, lembaga teknis seperti Philippine Institute of Volcanology and Seismology (PHIVOLCS), Philippine Atmospheric, Geophysical and Astronomical Services Administration (PAGASA), National Mapping and Resource Information Authority (NAMRIA), UP Resilience Institute dan Mines and Geoscience Bureau (MGB) telah membuat mandat untuk penilaian resiko multi-hazard seperti erupsi vulkanik, gempa bumi, tsunami, longsor, dan angin topan. Hal ini dapat membantu untuk melakukan respons bencana karena adanya penilaian resiko yang dapat memprediksi bencana yang akan terjadi.

Prioritas kedua SFDRR mengenai penguatan tata kelola bencana untuk mengatasi resiko bencana juga telah diupayakan Filipina. RA 10121 masih menjadi fondasi hukum nasional terkuat dalam menyediakan instrument legal dan kerangka kebijakan dalam pengurangan resiko bencana dan manajemen. Sementara, di dalam pengaturan lembaga NDRRMC menjadi lembaga tertinggi dalam pembuatan keputusan dengan tingkat DRRMC yang tersedia di setiap area, provinsi, kota/kabupaten, dan barangay serta BDRRMC yang bertanggung jawab dalam melaksanakan operasi manajemen bencana di wilayah masingmasing sesuai dengan peraturan pengurangan resiko bencana dan manajemen.

Kemudian, prioritas ketiga SFDRR mengenai investasi pengurangan resiko bencana untuk ketahanan telah dilakukan sejak 2008 oleh National Economic and Development Authority (NEDA) yang telah mengembangkan pengurangkan resiko bencana. Di dalam RA 10121 disebutkan bahwa pendanaan bencana untuk daerah tidak boleh kurang dari 5\% dari pendapatan regular yang harus disisihkan untuk pengurangan resiko bencana dengan rasio 70\% untuk pencegahan, mitigasi, dan kesiapsiagaan dan 30\% didedikasikan untuk Quick Response Fund (QRF). Department of Finance Filipina juga telah mengelaborasi strategi perlindungan keuangan nasional untuk meningkatkan ketahanan terhadap resiko bencana.

Terakhir untuk prioritas keempat SFDRR yaitu menambah persiapan bencana untuk respon efektif dan "Build Back Better" dalam pemulihan, rehabilitasi, dan rekonstruksi. Pemerintah Filipina telah menyusun NDRP dan NDRRMP dan diadopsi untuk berbagai bahaya dan skenario bencana dengan partisipasi pemangku kepentingan, termasuk masyarakat sipil dan sektor swasta. Pusat operasi NDRRMC juga telah dibentuk untuk pemantauan, evaluasi, dan koordinasi operasi tanggap bencana dengan OCD melakukan Penilaian Risiko dalam masa pra bencana, Actions Programs and Protocols (PDRA-APP), dan peningkatan kapasitas untuk kesiapsiagaan darurat, Incident Command System, Search and Rescue dan Post-Disaster Needs Assessment (PDNA). OCD, dalam kemitraan dengan mitra pemerintah lainnya, termasuk DILG, dan Philippine Public Safety College (PPSC) terus mendukung pemerintah daerah tentang manajemen bencana.

\section{Urgensi Sendai Framework for Disaster Risk Reduction}

Jika melihat kerangka kerjasama serupa seperti Paris Agreement, SFDRR lebih membahas mengenai manajemen bencana sementara di dalam Paris Agreement lebih membahas mengenai adaptasi perubahan iklim. Kedua kerangka kerjasama tersebut tidak mengikat negara secara hukum, tetapi dalam prosesnya Paris Agreement dibahas oleh para 
negosiator dan mereka sepakat bahwa perjanjian ini harus mengikat secara hukum untuk memberi dorongan bagi negara untuk merancang dan memperbarui kontribusi yang ditentukan secara nasional untuk mencapai emisi nol bersih pada tahun 2050 dan membatasi pemanasan global hingga $2^{\circ}$ Celsius. Negara-negara ini harus melaporkan kemajuan mereka di dalam konferensi seperti Conference of Parties 26 (COP26) (MacLellan, 2021).

Sementara itu, SFDRR yang tidak mengikat secara hukum sehingga membuat negara tidak merasa diwajibkan untuk meningkatkan standar manajemen bencana mereka. Padahal bencana juga dapat terjadi seiring dengan perubahan iklim sehingga dapat menjadi tindakan efektif bagi negara untuk mempersiapkan dan merespon saat ada kejadian darurat di negaranya masing-masing apabila terjadi bencana. Jika melihat dampak SFDRR di Filipina sendiri yang menjadikan SFDRR menjadi panduan utama dalam segala kebijakan mengenai pengurangan resiko bencana, SFDRR perlu juga menjadi perhatian bagi seluruh negara melihat dampak bencana yang dapat menganggu kehidupan masyarakat di segala aspek seperti aspek ekonomi, lingkungan, dll.

\section{SIMPULAN}

Filipina sebagai negara yang rentan akan bencana dengan letak geografisnya di Cincin Api Pasifik perlu menyiapkan segala upaya untuk mengatasi bencana. Bencana demi bencana seringkali menimpa negara Filipina seperti angin topan, siklon tropis, gempa bumi, banjir, dan lainnya. Rangkaian bencana yang terjadi dari tahun 2016-2020 di Filipina telah memberikan pemahaman penuh akan pentingnya kebijakan, kapasitas, investasi untuk PRB, dan pendanaan. Seluruh upaya PRB telah dilakukaSayangnya, upaya pemerintah nasional Filipina ini tidak terdistribusi dengan baik. Kunci dari PRB yang baik menurut teori human security salah satunya adalah kolaboratif dan transdisipliner di seluruh cakupan wilayah baik internasional, regional, nasional, wilayah, provinsi, kota/kabupaten, dan barangay. Tetapi, prioritas SFDRR seringkali terlihat hanya dipahami oleh pemerintah nasional ataupun lembaga internasional saja tanpa melihat bahwa terdapat beberapa pemerintah daerah yang masih belum menerapkan prioritas SFDRR secara baik. dengan SFDRR sebagai salah satu panduannya.

Namun, melihat hambatan dan pelaksanaan yang terjadi di Filipina selama tahun 2016-2020 dalam mengatasi bencana dengan panduan norma internasional seperti SFDRR, peneliti ingin menyampaikan beberapa saran untuk pemangku kebijakan dan organisasi yang fokus akan bencana. Pertama, peneliti melihat perlunya dibentuk Departemen Bencana dalam jajaran kabinet pemerintah di Filipina. Bencana selalu menjadi isu sampingan dan Filipina telah membentuk NDRRMC sebagai badan manajemen bencana. Namun, melihat struktur organisasi yang diisi oleh departemen pemerintah yang menyebabkan seakan-akan berjalan sendiri karena masing-masing departemen memiliki kepentingannya sendiri, rasanya perlu untuk Filipina membentuk departemen khusus untuk bencana karena negaranya yang memang rentan akan bencana. Kedua, Filipina perlu memastikan ketersedian informasi mengenai bencana mudah diakses dan penelitiannya dapat didukung untuk memberikan pemahaman mendalam akan resiko bencana di Filipina. Selain dapat membantu kinerja pemerintah dan organisasi yang bergerak di bidang bencana, masyarakat juga dapat terbantu dengan akses informasi ini agar dapat melakukan persiapan lebih sebelum terjadinya bencana dan meminimalisir kerugian yang mereka alami. Ketiga, Filipina telah mengatur pengalokasian dana untuk fase persiapan adalah $70 \%$ sesuai dalam RA 10121. Tetapi melihat praktek yang terjadi di lapangan, dana yang digunakan lebih banyak dikeluarkan dalam fase respons bencana. Hal ini tentunya menghambat respons efektif dan kepentingan "Build Back Better" karena proses evakuasi dan kerugian yang dialami akan lebih besar daripada jika pendanaan lebih difokuskan untuk fase persiapan. Selanjutnya, koordinasi antara pemerintah daerah dan pemerintah nasional serta kerjasama internasional perlu diberikan perhatian khusus. Kejelasan koordinasi ini penting untuk memberikan informasi mengenai apa saja 
yang sebenarnya dibutuhkan saat wilayah terjadi bencana dan apakah kebutuhan para korban telah terpenuhi.

\section{DAFTAR PUSTAKA}

AHA Centre. (2020). 12 Years of the ASEAN-ERAT Missions. Retrieved from The Column AHA Centre: https://thecolumn.ahacentre.org/insight/vol-67-12-years-of-the-aseanerat-missions/

Azis, A. (2004). Menelaah Konsep Human Security: Studi Kasus Penanganan Masalah Pengungsi Afghanistan di Australia (1999-2002). Global Vol 7 No 1 November 2004, 82-83. DOI: Retrieved from https://doi.org/10.7454/global.v7i1.235

Bakry, U. (2016). Metode Penelitian Hubungan Internasional. Yogyakarta: Pustaka Pelajar.

CEDM-HA. (2018). Philippines Disaster Management Reference Handbook. Hawaii: Center for Excellence in Disaster Management \& Humanitarian Assistance.

Commision on Audit. (n.d.). Disaster Management Practices in the Philippines: An Assesment. Philippines: Commision on Audit Republic of the Philippines.

Doroteo, H. (2015). Philippines: Disaster Risk Profile and Disaster Risk Reduction (DRR) Framework: Natural Calamities. Retrieved from https://www.researchgate.net/publication/287817230_Disaster_Risk_Profile_and_Dis aster_Risk_Management_Framework_of_the_Philippines_Natural_Disasters

MacLellan, L. (2021, November 22). Is The Paris Climate Agreement Legally Binding? Expert Explain. Retrieved from World Economic Forum: https://www.weforum.org/agenda/2021/11/paris-climate-agreement-legally-binding/

OCD. (2020). National Disaster Risk Reduction and Management Plan 2020-2030. Queson City: Office of Civil Defense - Policy Development and Planning Service.

PMI. (2007). Pelatihan KSR Dasar: Kumpulan Materi. Jakarta: Palang Merah Indonesia.

Purnama, S. (2017). Modul Manajemen Bencana. Bali: Fakultas Kedokteran Universitas Udayana.

Ramadayanti, E. (2020, March 26). Covid-19 dalam Perspektif One Health Approach dan Law Enforcement. Retrieved from FH Unpad: https://fh.unpad.ac.id/covid-19-dalamperspektif-one-health-approach-dan-law-enforcement/

Raymond, G. (2021). International Norms and the Resort to War. Boise: Boise State University.

Sinulingga, A. (2016). Isu Bencana dan Prinsip-Prinsip Humanitarian Dalam Studi Ilmu Hubungan Internasional. Andalas Journal of Internasional Studies Vol. 5 No. 1, 1727. DOI: https://doi.org/10.25077/ajis.5.1.17-27.2016

Wisner, B. (2020). Five Years Beyond Sendai: Can We Get Beyond Frameworks? International Journal of Disaster Risk Reduction, 239-249. Retrieved from https://link.springer.com/article/10.1007/s13753-020-00263-0 
World Bank. (2005). Natural Disaster Risk Management in the Philippines: Enhancing Poverty Alleviation Through Disaster Reduction. World Bank. URI:

http://hdl.handle.net/10986/8748

Zartman, I., \& Touval, S. (2010). International Cooperation: The Extents and Limits of Multilateralism. Cambridge: Cambridge University Press. 